

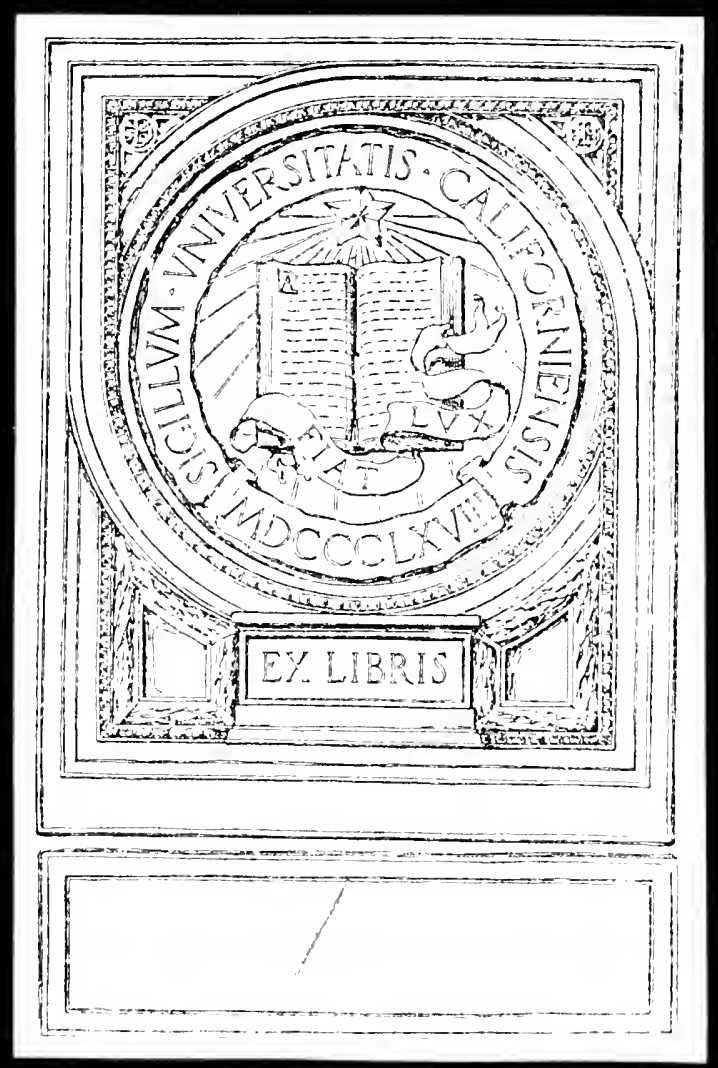




\section{THE BOOK DIVINION OE PROPERTIIS}

By B. L. ULLMiN

The problem of the book division of Propertins is one that is faniliar to all students of that guthor.' Lachmann was the first to challenge the division into four books which the MSti shen, and to propose a division into five books. His views brought on a controversy which has lasted to the present day. ()nly one? serious objection, outside of the testimony of the Mss', has beren raised against Lachmann's theory. Nonius Marecllus (16i.MI) under the word secundure has Propertins Elegiomm lih. III followed by a quotation of iii. 21. 14 according to the MI division, or iv. 21. 14 according to Lachmann's division. The Lachmamn adherents met this by saying that the MSS were wrong, that Nonius wrote iiii not iii. Müller and Lindsay, accordingly, adopted this change in their editions of Nonius, the former noting that the vulgate reading was $\mathrm{ii}$, the latter making no comment whatewer in his scanty apparatus. Quicherat and Onions retained iii, without comment. Birt, ${ }^{2}$ after a rery careful and searching investigation, found another solution. His theory is that the first hook was published separately and was called the Monobiblos, a name which is supported by MS authority and by an ancient title to one of the apophoreta of Martial. The rest of the poems were published, perhaps two books at a time, to make up one volume under the title of Elrgir. Naturally they were numbered from 1 to 4 , not from 2 to 5, as in Lachmann's scheme. In this arrangement the citation in Nonius actually tomes in the third book of the Elegies, as Nonius calls them.

It seemed to me desirable to make sure that the MSS of Nonius actually had iii, not iii. Lindsay, ${ }^{3}$ in discussing the Nonius tradition says: "Our original authorities for the text are thus reduced to (1) $\mathrm{L},(2) \mathrm{H}^{2} \mathrm{~V}$, and for books i-ii med. PE, (3) the to bear.

ISee Plessis, Etudes critiques sur Properce, for a résumé of the arguments brought

${ }^{2}$ Das antike Buchwesen, pp. 413-26. 3 class, lier. IX, [1, 35i.

[Clagaical Philology IV, January, 1904] 45 
extract MSS, (t) $\mathrm{F}^{3}$." The extract MSS do not concern us in the question under discussion, because they omit the Propertius citation. $\mathrm{P}$ stops before this point, and $\mathrm{E}$ in this part is a copy of $\mathrm{F}^{\prime} \quad$ Of the rest $\mathrm{I}$ have examined all but $\mathrm{V}$, and in addition all the MSS in Leyden. They all have III uncorrected, except L, the most important one, which originally had IIII, corrected by erasure to III, a state of affairs which nobody appears to have noticed. It is impossible to determine who made the correction. It may have been $\mathrm{L}^{1}, \mathrm{~L}^{2}$ (who used a MS of the "extract" class), or $\mathrm{L}^{3}$ (who used a MS of the "doctored" class). ${ }^{2}$ The question to decide is whether the common archetype of all the MSS had III or IIII. The evidence is at least two to one in favor of the former, i. e., that of $\mathrm{F}^{3}$ (which does not change III to IIII), ${ }^{3}$ and $\mathrm{H}^{2} \mathrm{~V}$ (though $\mathrm{I}$ have not seen $\mathrm{V}$, it is practically certain to have III. $\mathrm{H}$ has III, not touched by $\mathrm{H}^{2}$ ). I say at least, because the correction in $\mathrm{L}$ may have been made by $\mathrm{L}^{2}$ or $\mathrm{L}^{2}$ from the archetype. We must therefore decide that the common archetype probably had III.

There is one other question that seemed worth investigating in this connection. Hosius ${ }^{*}$ cites three MSS of Propertius which quote the Nonius passage and have in quarto libro written out. I examined the three and found that Vatic. 1612 is dated 1480 , Neapolit. IT. F. $22(270)$ is dated 1465, while Barber. VIII. 58, though not dated, clearly was written toward the end of the fifteenth century. On the other hand, I found that Ambros. H 46 sup., which appears to have been written about 1450 , also contains the Nonins passage, but has Propertius in III. $l^{\circ}$. It gives the Propertius line (Iam nitidum nautis anca secundd. ite' $)$ which the others omit, and besicles, the whole passage is phrased a little differently. Probably the three later MSS give a ehanged (and corrupted) version of the Ambrosian MS. At

1 (Onions' edition of Nonius, p. xx, Lindsay's edition, p. xxriii.

2 For these corrections see Lindsuy in A. J. P. XXII, p. 34.

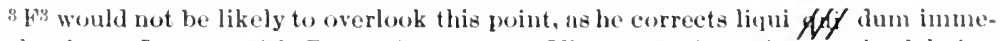
diatcly after. I agree with Brown (Cless. Rev. IX, 1, 450) in assigning the deletion to $\mathrm{F}^{\mathrm{s}}$. It is in the light brown ink. Lindsay, by implicution, makes it the same hand. (Cleess. Rere. $\mathrm{X}, \mathrm{p}, 16$.

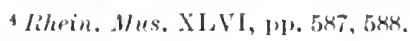


any rate the presence of the Propertins line in this US shows that its text does not come from any of the other Msiti or their archetypes.

I think I have shown that the common arehestye of the Nonius MSs had III, not IIII. That does not prove, however, that this is what Nonius himself wrote. The archetype may have been wrong: the interchange of IIII and III is a mistake easily made. In Book II of Nonius I find twenty-two cases of variation in the MSS cited in Onions' critical apparatus. It may be remarked that seventeen of these show IIII for III, and only five show III for IIII.

Birt's other arguments, though plausible, have not convinced all scholars, and further light, if it can be obtained, will not be without interest. After giving evidence tending to show that the first book remained separate from the rest of the elegies during antiquity, Birt (op. cit., p. 425 ) remarks that the Tetrabiblos was better known and more widely read than the Monobiblos. Evidence for this is the fact that, of eleven citations by the granmarians, none is from the first book, and that only among the wall inscriptions of Pompeii is there a reminiscence of a line from the first book. These facts are still more striking than Birt makes them. Eleven different passages of Propertius are quoted in Latin literature, accorching to Baehrens' edition, most of them by the grammarians. They are: ${ }^{1}$

ii. 1. 2: Caesius Bassus (K. TI. p. 264, 10)

ii. 3. 24: Macrobius (K. V, p. 626, 17)

ii. 9. 41: Serrius ad Verg. Buc. r. 21

ii. 13. 35: Charisius (K. I, p. 89, 23)

ii. 13. 35. De Dub. Nom. (K. V, p. 585, 5)

ii. 14. 1: Charisius (K. I, p. 67, 11)

ii. 33. 37: Charisius (K. I, p. 107, 28)

ii. 33. 37: De Dub. Nom. (K. V. p. 590, 24)

ii. 34. 65-66: Douatus Vit. Verg.

ii. 34. 65-66: Anth. Lat. I. 264

iii. 8. 37: Priscian (K. II, p. 536, 15)

iii. 8. 37: Diomedes (K. I, p. 369, 22)

iii. 11. 15: Charisius (K. I, p. 103. 17)

1 The manuscript numbering is followed. 
iii. 11. 15: De Dub. Nom. (K. V, p. 576, 22)

iii. 21. 14: Nonius Marc. (169 M)

iv. 1. 11-14: Lactantius Instit. ii. 6

is. 1. 13: Isidorus Orig. xviii. 4

Some of these passages are quoted more than once; in only one case is it probable that the quotations are independent: ir. 1. 11-14 are quoted by Lactantius, and line 13 is quoted also by Isidorus, who does not seem to have drawn from Lactantius. In addition it is clear that iv. 10.44 was originally cited in De Dub. Nom. K. V, p. 592, 5: Torques generis feminini, ut Propertius* 'torquem auream.' Keil's note to this hine reads: excidit Propertii uersus IIII. 10. 4 . torques ab incisa decidit unca gula. torques aureae ex Varrone attulit Nonius. ${ }^{1}$ Besides, Baehrens gives two quotations from the Pompeian wall inscriptions, one of iii. 16. 13-14 in CIL. IV. 1950 and the other of iv. 5. $47-45$ in CIL. IV. 1894. To this may be added a third, ii. 5. 9-10 in Acta inst. arch. R. 1875, p. 190 (Buecheler Carm. epig., p. 82:3). The grand total is sixteen, divided equally, strangely enough, among the last four books of Lachmamn's division or the four books of Birt's Elegia. Actual quotations only are to be taken into account, and imitations cannot be introduced as evidence, because it is not always possible to tell which is the initation and which the original. For example, CIL. IV. 1520 (cf. culd., p. 208), has the lines

Candida me docuit nigras odisse puellas

Odero se $(=\mathrm{si})$ potero se $(=\mathrm{si})$ non invitus amabo.

The second line is an exact citation of Orid $A m$. iii. 11. 35. The first has been compared to Prop. i. 1. j.

Donec me docuit cistas odisse puellats

Improbus (Amor)

1'ossibly there is a refurence to a lost poem of Propertius in the sume treatise,

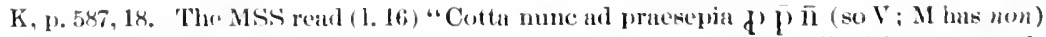

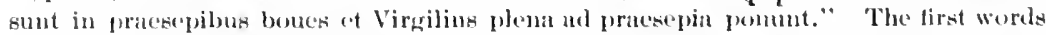

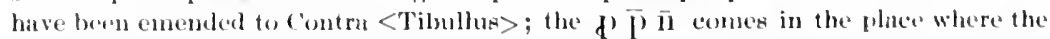
name of an author should come, as Keil points out. J1 may be a corruption of propertius, thromght the stages properti', f' ! ti'. This fits in very well with Lachman's and Birt sitheory that some of the porme of the first book of the Tefobiblos hate not eome down to un. 
Birt aceepts this as a rominisenere of our anthor. This dees not at all mean that the Pompeian wall-scribbler had rond the first book of Propertius. Thre npturss of the lines consists in their being direet quotations. A man is not likely to make up one line and answer it with a quotation from somebody alse. Moroover, parts of the first line are found elsewhere (1V. 152:3, 1521; 1524. $1536,3040)$ apparently written by ditferent people, which makes it probable that it was a well-known line as it stands. In that case, the poet who wrote it may have initated Propertius or vice versa.

But this is not the only evidence to be gleaned from the quotations. The one from Caesius Bassus is of particular interest. It necessitates an examination of the nature of the poetical quotations to be found in the Roman metricians. In general, it may be said that there are two kinds, first, lines or parts of lines showing some exception to a general rule. or some other peculiarity, in which case the choice of lines is, of course. limited: second, lines illustrating a class or a rule, as, for example, a hexameter line. Here the grammarian had thousands of lines to choose from. Naturally he chose the most familiar: the first line of the Aeneid. Most of such quotations were undoubtedly made from memory, or from memory refreshed by a glance at the original. Citations of this sort are not confined, however, to the first line or lines of the Aeneid, though these are the ones most frequently found. The first line of the second book also is common. The better known the poet. the more various the quotations. So the first lines of many of the Epodes of Horace are quoted, though those of the first and second Eporles are much more frequently net with. The second Epode seems to have been more popular than the first, to judge from the number of quotations. In the case of the Odes, the first line of the first poem illustrating a certain meter is the one usually given. For less well-known poets, the range from which quotations of this sort are taken is more limited. The use of the first line of the work is the rule. The case of Tibullus is in point. He is quoted five times in what may be called the "general" way (deseribed above) by the metricians. $\mathrm{He}$ is quoted once by Diomedes (K. I, p. 454, 19) in illustration 
of his definition of an elegy as a poem consisting of hexameter and pentameter lines in alternation. The verses given are i. 1. $1-2$, as was to be expected. The other four quotations are all of the line, i. 1. 6. It is chosen because it is the first "perfect" (i. e., dactylic) pentameter in Tibullus; lines 2 and 4 each have one spondaic foot. In the metrical fragment of Keil VI. p. 612, 12 , it is quoted as a normal pentameter line. In the other three cases (K. VI, p. 616,15 , p. 127,7 , and p. 264,14 ), it is quoted as a pentameter line for use as a base from which to form other meters. It is now possible to apply the principle just discussed to Propertius. The only quotation in the metrical writers is that in Caesius Bassus, and this occurs in connection with the Tibullus line just mentioned (K. VI, p. 264, 10.) The passage discusses the formation of the choriambic verse, and an illustration is given of the way in which such a verse is formed from a pentameter line:' ad summam pentametrum heroum, qui habet dactylos primos duos, velut hunc,

unde meus reniat mollis in ora liber,

anliectis duabus syllabis longis facies choriambicum ex heroo pentametro sic,

unde meus nunc reniat mollis in haec ora liber,

et

sic,

$$
\text { dum meus assiduo, lnceat igne focus }
$$

dum meus hic assiduo luceat hoc igne focus.

The second quotation is the one from Tibullus, the first is from Propertius ii. 1. 2. This is surprising. Why is i. 1 not quoted? Is there no normal dactylic pentameter line in i. 1? But there is: i. 1.4 .

Et caput impositis pressit Amor pedibus

which can be changed to a choriambic line in this way,

Et cetput (hoc) impositis pressit Amor (tum) pedibus.

Failing this, there were i. 1. 14, i. 2. 6 and many others in the first book. Why was the first book ignored? Two answers are

The mammeripts are confused here, but Keil's text is probuble. The point at issue is not affected. 
possible: one, that the first book was not the first, but was farther on, perhaps last, in Caesius' manuseript of Propertius; the other, that it was not a part of the book of elegres which Cresius prossessed. When the other evidence is taken into consideration, that of the sixteen quotations from the later books as ngainst none from the first, and that which Birt adduces, we must conclude that the second is the correct answer, and we may say with a great deal more confidence than before that the first book was not a part of the book of Propertian "Elegries" known to antiquity.

The University of Chicago 


\title{
THE VERBAL IN -TEO IN POLYBIUS
}

\author{
By Hamilton Ford Allen
}

The use of the verbal adjective in - $\tau \epsilon o$ "from Homer to Aristotle, exelusive" has been studied and the results of that study have been published, ${ }^{1}$ so that we have a sound basis for the examination of the use of this verbal in the $\kappa o \iota \nu \eta$ as represented in Polybius. In view of the completeness of Bishop's treatment of the verbal, it will be enough if we present the results of our study of the use of the verbal in - $\tau \epsilon o$ in Polybius and refer the reader to Bishop for comparison.

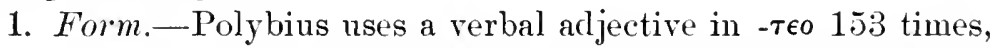
formed from 70 different verbs, simple 39, compound 31 (B., p. 5 ). From 48 of these verbs a verbal is formed once, from 11 twice, from 2 three times, from 3 four times, from 1 ( $\delta i \delta \omega \mu l) 6$ times,

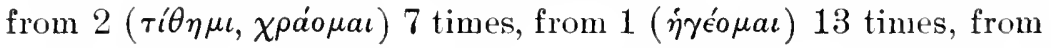

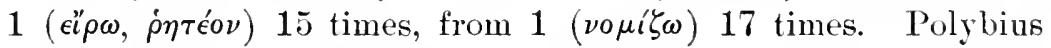
is not peculiar in using the same verbal many times (B., p. 5 ). The verbal is formed from $46 \omega$-verbs, from $12 \mu a l$-verbs and from $12 \mu t$-verbs in which Polybius shows no decided preference for any one class as compared with the authors examined by B. (P. 4 ). Polybius does not form the verbal in any new way (B., pp. $3 \mathrm{f}$.).

2. Use.-In spite of the fact that the majority of the verbs from which Polybius forms verbal adjectives are used transitively

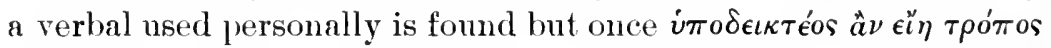
3. 36. 5. In view of the fact that Polybius has studiously avoided the personal use of the verbal, Goetzeler ${ }^{2}$ ascribes this one oecurrence to a scribal error and would emend aceordingly. He thinks that Polybius uses the impersonal verbal in imitation of Latin, which, at the period at which he wrote, saicl: opmugnamelum est Athences; in support of this he quotes Draeger and Wölflin.

"Ohurles Edward Biblop, "The Greek Verbal in -теo," Am. Journ. Phil. XX (1899), pp. 1-21, 121-38, 241-53, eited as 13. in this urticle. For liternture of the subject see B.. 1. 2, note.

${ }^{2}$ Ludovicus Goctzcler De Polybii Elocutione (W'ìrzburg, 1887), mp. $29 \mathrm{f}$.

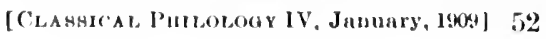




\section{RETURN TO: CIRCULATION DEPARTMENT 198 Main Stacks}

$\begin{array}{cccc}\begin{array}{c}\text { LOAN PERIOD } \\ \text { HOME Use }\end{array} & 1 & 2 & 3 \\ 4 & 4 & 5 & 6\end{array}$

ALL BOOKS MAY BE RECALLED AFTER 7 DAYS.

Renewals and Recharges may be made 4 days prior to the due date Books may be renewed by calling 642-3405.

\section{DUE AS STAMPED BELOW.}

AR 23200?

FORM NO. DD 6 $50 M$
UNIVERSITY OF CALIFORNIA. BERKELEY Berkeley. Calıfornia 94720-6000 


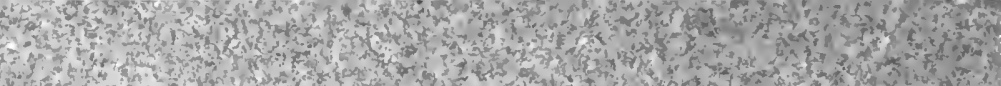

